Original Article

\title{
Variations in heterochromatin content reveal important polymorphisms for studies of genetic improvement in garlic ( Allium sativum L.)
}

\author{
Conteúdo de heterocromatina revela polimorfismos importantes para o melhoramento \\ genético do alho (Allium sativum L.)
}

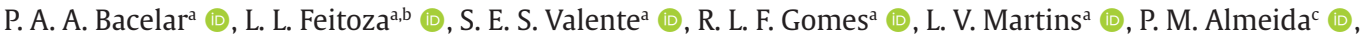 \\ V. B. Silva ${ }^{\mathrm{a}}$ (D) A. C. A. Lopes ${ }^{\mathrm{a}}$ (D), R. Carvalho ${ }^{\mathrm{b}}$ (D) and A. P. Peron ${ }^{\mathrm{a}, \mathrm{d}^{*}}$ (D) \\ aUniversidade Federal do Piauí - UFPI, Centro de Ciências Agrárias - CCA, Programa de Pós-graduação em Agronomia - PPGA, Teresina, PI, \\ Brasil \\ bUniversidade Federal Rural de Pernambuco - UFRPE, Departamento de Biologia, Recife, PE, Brasil \\ 'Universidade Estadual do Piauí - UESPI, Faculdade de Ciências Médicas - FACIME, Teresina, PI, Brasil \\ dUniversidade Tecnológica Federal do Paraná - UTFPR, Departamento de Biodiversidade e Conservação da Natureza - DABIC, Campo Mourão, \\ PR, Brasil
}

\begin{abstract}
Allium sativum L. is an herb of the Alliaceae family with a specific taste and aroma and medicinal and nutraceutical properties that are widely marketed in several countries. Brazil is one of the largest importers of garlic in the world, despite of its production is restricted and limited to internal consumption. Thus, explore the genetic diversity of commercial garlic conserved at germplasm banks is essential to generate additional genetic information about its economically important crop. A suitable tool for this purpose is the cytogenetic characterisation of these accessions. This study aimed to characterise the cytogenetic diversity among seven accessions of garlic from a Germplasm Bank in Brazil. The karyotypes were obtained by conventional staining and with chromomycin $\mathrm{A}_{3}(\mathrm{CMA})$ and 4,6-diamidino-2-phenylindole (DAPI) fluorochromes. All accessions analysed showed chromosome number $2 n$ $=16$, karyotype formula $6 \mathrm{M}+2 \mathrm{SM}$, symmetrical karyotypes, reticulate interphase nuclei, and chromosomes with uniform chromatin condensation from prophase to metaphase. The fluorochromes staining showed differences in the amount and distribution of heterochromatin along the chromosomes and between accessions studied. Based on the distribution pattern of these small polymorphisms, it was possible to separate the seven accessions into three groups. It was also possible to differentiate some of the accessions individually. One of the results obtained showed a heteromorphic distension of the nucleolar organiser region observed on the chromosome pairs 6 or 7 with peculiar characteristics. It was suggested for example, that the heteromorphic block of heterochromatin $\left.\left(\mathrm{CMA}^{+++} / \mathrm{DAPI}\right)^{-}\right)$on chromosome 6 of the "Branco Mineiro Piauí" accession can be used as a marker to identify this genotype or may be associated with some character of economic interest.
\end{abstract}

Keywords: garlic accessions, germplasm bank, cytogenetics, polymorphisms.

\begin{abstract}
Resumo
Allium sativum L. é uma erva da família Alliaceae com sabor e aroma específicos e propriedades medicinais e nutracêuticas amplamente comercializada em diversos países. O Brasil é um dos maiores importadores de alho do mundo, apesar da sua produção ser restrita e limitada ao consumo interno. Assim, explorar a diversidade genética do alho comercial conservado em bancos de germoplasma é essencial para fornecer informações genéticas adicionais acerca dessa cultura economicamente importante. Uma ferramenta adequada para esse fim é a caracterização citogenética desses acessos. Este estudo teve como objetivo caracterizar a diversidade citogenética entre sete acessos de alho de um Banco de Germoplasma no Brasil. Os cariótipos foram obtidos por coloração convencional e com os fluorocromos de cromomicina $\mathrm{A}_{3}$ (CMA) e 4,6-diamidino-2-fenilindol (DAPI). Todos os acessos analisados apresentaram número cromossômico $2 n=16$, fórmula cariotípica $6 \mathrm{M}+2 \mathrm{SM}$, cariótipos simétricos, núcleos reticulados em intérfase e cromossomos com condensação uniforme da cromatina da prófase para a metáfase. A coloração com fluorocromos mostrou diferenças na quantidade e distribuição de heterocromatina ao longo dos cromossomos e entre os acessos estudados. Com base no padrão de distribuição desses pequenos polimorfismos, foi possível separar os sete acessos em três grupos. Também foi possível diferenciar individualmente alguns dos acessos. Um dos resultados obtidos mostrou distensão heteromórfica da região organizadora nucleolar observada nos pares
\end{abstract}

*e-mail: anaperon@utfpr.edu.br

Received: September 12, 2020 - Accepted: January 26, 2021

This is an Open Access article distributed under the terms of the Creative Commons Attribution License, which permits unrestricted use, distribution, and reproduction in any medium, provided the original work is properly cited. 
dos cromossomos 6 ou 7 com características peculiares. Foi sugerido, por exemplo, que o bloco heteromórfico de heterocromatina (CMA ${ }^{++} /$DAPI') no cromossomo 6 do acesso "Branco Mineiro Piauí" pode ser usado como um marcador para identificar esse genótipo ou pode estar associado a algum caráter de interesse econômico.

Palavras-chave: acessos de alho, banco de germoplasma, citogenética, polimorfismo.

\section{Introduction}

The genus Allium L. contains over 700 species, including Allium sativum L. (garlic), which is a temperate climate species widely used for seasoning in food preparation (Jayaswall et al., 2019). Garlic is an aromatic plant and one of the most widely cultivated vegetable crops in the world for use as a condiment or for the extraction of secondary compounds for medicinal and pharmaceutical purposes (Yoshimoto and Saito, 2019). A. sativum is a diploid species that is difficult to flower and is vegetatively propagated, as the absence of viable reproductive organs precludes the production of true seeds or the use of conventional breeding methods (Rup, 2019). Thus, the lack of meiotic recombination and the accumulation of somatic mutations greatly limit the genetic variability of garlic, a fact that potentiates the spread of diseases across generations, causing damage to commercial clones and consequently low production (Malik et al., 2020). Therefore, the number of features available for the identification of cultivars is limited, and in general, characteristics such as width and number of leaves, colour, and the weight of the cloves are the characteristics most commonly used but not always easy to determine.

Garlic breeding programs primarily seek to obtain new genotypes by improving existing cultivars (Honorato et al., 2013; Ebert, 2020). In Brazil, garlic also has socioeconomic importance and, in some states, has been produced as a source of income in family farming systems for small and medium-size farmers, where local or land races garlic cultivars are predominantly used (Santos and Gomes, 2012; Landau et al., 2020). These cultivars exhibit genetic diversity that can be exploited for the selection of improved genotypes for production and commerce, because production has decreased considerably in recent decades due to competition with garlic imported mainly from China and Argentina (Paladini, 2019). Thus, the successful selection of new cultivars depends on the ability to identify the existing genetic diversity among accessions from a germplasm bank and the ability to measure this diversity using tools such as biochemical, molecular, and cytogenetic markers, among others.

Chromosomal analysis has been extensively used for the karyotypic characterisation of different groups of plants, allowing the understanding of phylogenetic relationships and the detection of genetic diversity among taxa. Information such as chromosome number and size, morphology, and heterochromatin distribution, among other characteristics, is important for this type of study (Martins et al., 2018; Cordeiro et al., 2020; Querino et al., 2020). It is known that the genus Allium exhibits variation in regards to the chromosome number of its members and wide plasticity in base chromosome number, with reports of $x=7,8,10$ and 11 (Xie-Kui et al., 2008; Khar et al., 2020).
However, typically, members of the A. sativum species have large chromosomes with a predominance of metacentric chromosomes and a symmetrical karyotype, with the base number $x=8$ being the one most commonly found. The diploid set is usually $2 n=2 x=16$ but may show variations, namely, $2 n=2 x=12$ and $2 n=2 x=18$ (Yüzbasioglu and Ünal, 2004). Cytogenetic studies in Allium are quite scarce and some cases restricted to classical techniques such as conventional staining and C-banding (Mukherjee and Roy, 2012).

Thus, the study aimed to detect karyotypic variations and to locate and determine the heterochromatin content in seven Brazilian cultivars of A. sativum L. For that purpose, conventional staining techniques and the base-specific fluorochromes chromomycin $\mathrm{A}_{3}$ (CMA) and 4,6-diamidino2-phenylindole (DAPI) were used. The results obtained can help the selection and identification of accessions for future application in garlic breeding programs.

\section{Material and Methods}

Seven accessions from the collection of the Active Garlic Germplasm Bank of the Luiz de Queiroz College of Agriculture - University of São Paulo (Escola Superior de Agricultura ‘Luiz de Queiroz’ - Universidade de São Paulo; ESALQ-USP) were used. The analyses were conducted at the Laboratory of Plant Cytogenetics of the Federal Rural University of Pernambuco, Brazil. Common names and the origins of the accessions are shown in Table 1.

Root tips were pretreated in $0.2 \%$ colchicine for $18 \mathrm{~h}$, fixed in Carnoy solution of ethanol:acetic acid (3:1, v/v), and stored at $-20^{\circ} \mathrm{C}$. Conventional staining followed the protocol of Guerra and Souza (2002). The root tips were hydrolysed with $5 \mathrm{~N} \mathrm{HCl}$ for $20 \mathrm{~min}$, crushed in a drop of $45 \%$ acetic acid, and frozen in liquid nitrogen for removing the coverslip. The slides were stained with $2 \%$ Giemsa. The double staining with $\mathrm{CMA}_{3}$ and DAPI was performed according to Schweizer and Ambros (1994). Slides aged for three days were stained with $\mathrm{CMA}_{3}(0.5 \mathrm{mg} / \mathrm{ml})$ for $60 \mathrm{~min}$ and stained with DAPI $(2 \mathrm{mg} / \mathrm{ml})$ for $30 \mathrm{~min}$. Later, the slides were mounted in glycerol:Mcllvaine buffer $\mathrm{pH} 7.0$ $(1: 1, \mathrm{v} / \mathrm{v})$ mounting medium containing $2.5 \mathrm{mM} \mathrm{MgCl}$. The slides were aged for more than three days before analysis to stabilise the fluorescent labelling. Slides were photographed using a Leica DFC 345 FX digital camera coupled to a Leica DM 2500 epifluorescence microscope. Only the brightness and contrast of the images were adjusted in Adobe Photoshop CS3 with the support of Paint Shop Pro 5.

Images of five metaphases from each accession were used for morphometry. The size of chromosomes was determined using the Micromeasure 3.3 software supplemented with Microsoft Excel 2010. Once the 
karyotypes were measured, it was possible to determine the values of total chromosome length (TCL) and its mean (MCL); the total length of the haploid set of chromatin (TLHS), which was obtained by summing the haploid karyotype; the length of the long arm (q); the length of the short arm (p); and the ratio between the length of the long and short arms $(r)$ of each chromosome pair. These values were used to calculate the chromosomal asymmetry indices of Huziwara (1962), TF\%, and Zarco (1986), $A_{1}$ and $A_{2}$.

For statistical analysis, mean values per metaphase were considered to be variables for the total length and for the length of the long and short arms, adopting a completely randomised experimental design with five replicates. The model adopted was as follows (Equation 1):

$$
Y_{i j}=m+t i+e\left({ }_{i j}\right)
$$

where: $Y_{i j}=$ observation of accession $i$ in replicate $j=1$, $2, \ldots, 5 ; \mathrm{m}=$ overall mean; $\mathrm{t}_{\mathrm{i}}=$ effect of accession $\mathrm{i}$, with $\mathrm{i}=1,2, \ldots \mathrm{n} ; \mathrm{e}_{(\mathrm{iij})}=$ experimental error.

We performed the Shapiro-Wilk test, which suggested a parametric distribution of our data. Next, an analysis of variance was performed, followed by Tukey's test at a $5 \%$ significance level using the Genes software (Cruz, 2013).

\section{Results and Discussion}

All accessions analysed had a chromosome number $2 n=2 x=16$ (Figures 1 and 2), confirming previous

Table 1. Identification and origin of the accessions used for the cytogenetic characterisation of A. sativum.

\begin{tabular}{|c|c|c|}
\hline Accession $\mathbf{n}^{0}$ & Accession & Origin \\
\hline 1 & Sussuapara - PI & Collections in crop areas, fairs, and street markets in Picos, Piauí, Brazil \\
\hline 2 & Santo Antônio de Lisboa - PI & \\
\hline 3 & Catetinho do Paraná 1254 & $\begin{array}{l}\text { Agronomic Institute of Campinas (Instituto Agronômico de Campinas -IAC), São Paulo, } \\
\text { Brazil }\end{array}$ \\
\hline 4 & Branco Mineiro - PI & $\begin{array}{l}\text { National Research Center for Vegetable Crops (Centro Nacional de Pesquisas de } \\
\text { Hortaliças - CNPH) and corresponds to an accession derived from a collection in } \\
\text { Piauí, in } 1976\end{array}$ \\
\hline 5 & Cateto Roxo 99 & Agronomic Institute of Campinas (IAC), São Paulo, Brazil \\
\hline 6 & Roxo de Minas & Luís de Queiroz College of Agriculture (ESALQ), São Paulo, Brazil \\
\hline 7 & Sergipe & Luís de Queiroz College of Agriculture (ESALQ), São Paulo, Brazil \\
\hline
\end{tabular}



Figure 1. Allium sativum L. cytological data obtained by conventional Giemsa staining. Prophase and interphase nucleus (A), prometaphase (B), and metaphase (C) obtained with the use of antimitotic. Mitotic cycle is shown in d-f: anaphase (D), end of anaphase (E), and telophase (F). Dots and red arrow indicate the distended nucleolar organiser region (NOR). Bar $=10 \mu \mathrm{m}$. 


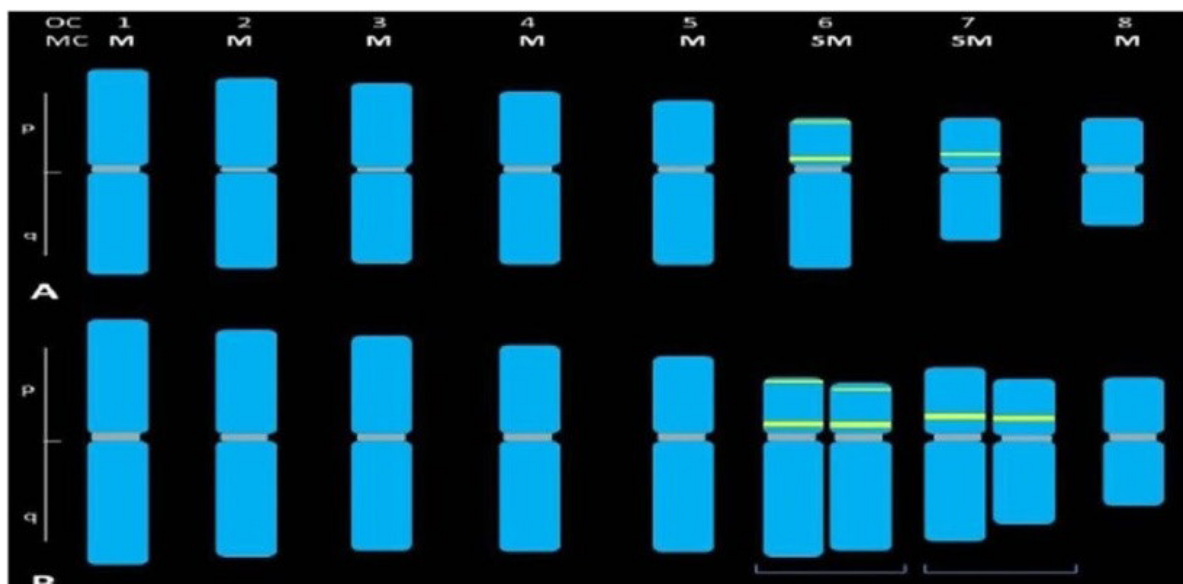

B


C

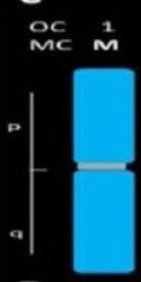

$m^{2}$
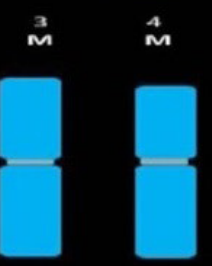

$\stackrel{s}{M}$

6
$5 \mathrm{M}$

m

$\stackrel{8}{\mathrm{~m}}$
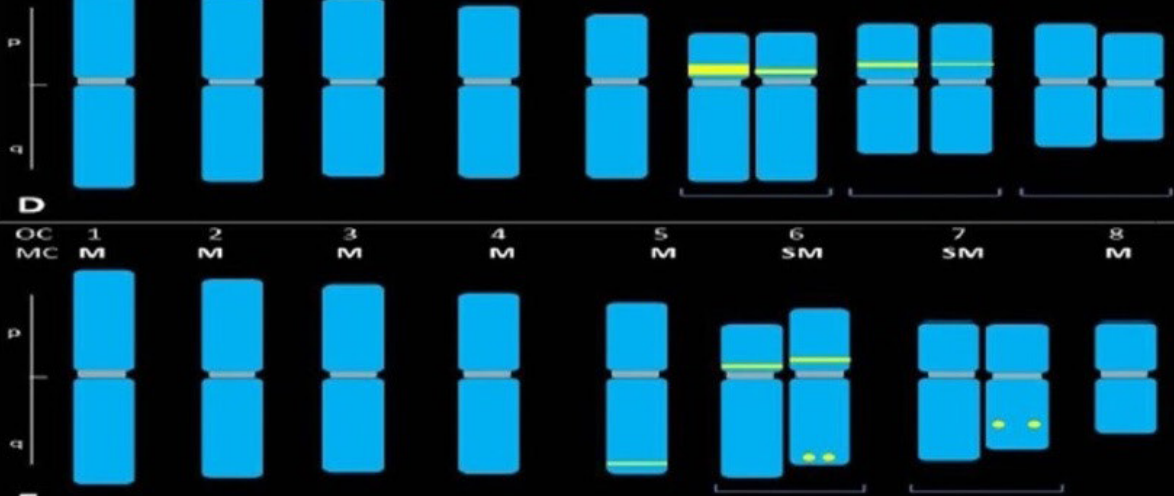

$\mathbf{E}$

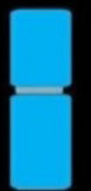

$\stackrel{\mathrm{s}}{\mathrm{M}}$


$\stackrel{8}{\mathrm{M}}$
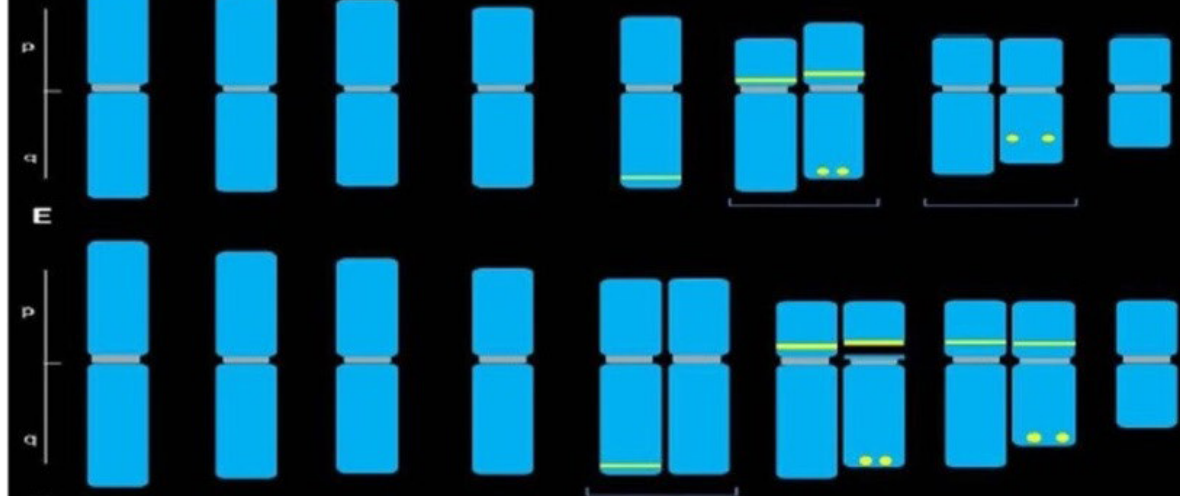

F
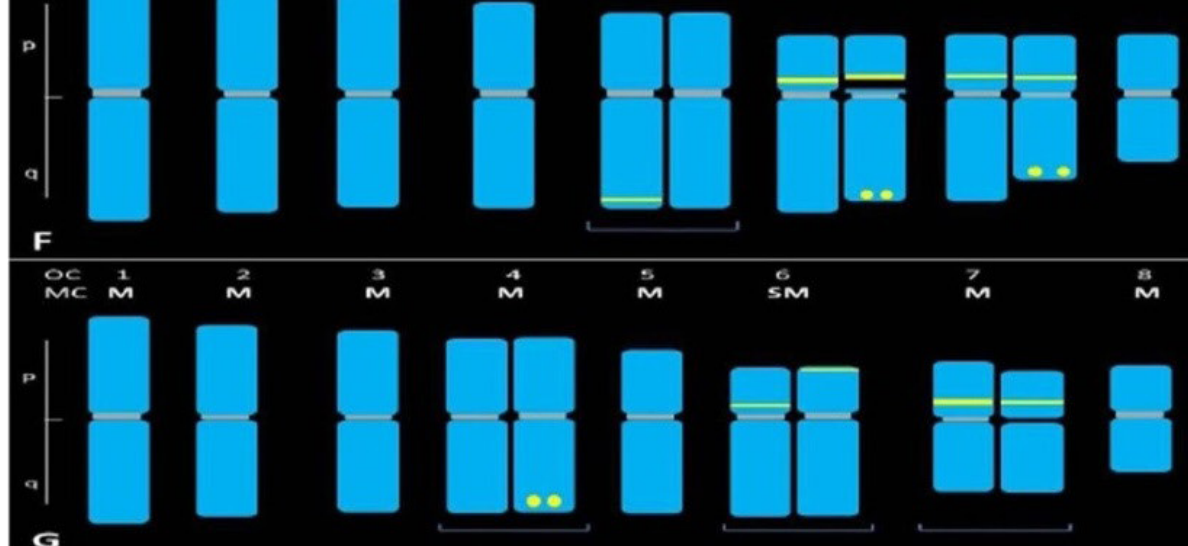

Figure 2. Idiograms of the accessions "Sussuapara - PI" (A), "Santo Antônio de Lisboa - PI" (B), "Catetinho do Paraná 1254" (C), "Branco Mineiro - PI" (D), "Cateto Roxo 99" (E), "Roxo de Minas" (F), and "Sergipe” (G). Yellow dash and circle represent the CMA ${ }^{+} / \mathrm{DAPI}^{-}$band. Chromosomal order (CO), chromosome morphology (CM), metacentric (M), submetacentric (SM), short arm (p), and long arm (q). Vertical bar in karyogram and ideogram $=10 \mu \mathrm{m}$. 
accounts (Konvicka and Levan, 1972; Sukias and Murray, 1990; Mukherjee and Roy, 2012). The chromosomes of species from the genus Allium have been described since the pioneering studies of Levan (1935) and Nichols (1941), who found the same diploid number for other species of the genus Allium, such as A. albopilosum, A. ammophilum, A. nutans, and A. cepa. However, Ordóñez et al. (2002) also reported the presence of haploid plants of $A$. sativum with $n=8$ in addition to aneuploid and polyploid plants with $2 n=2 x=28,30$, and 32 .

For all accessions, the interphase nucleus exhibited a reticulate structure, with dense and evenly distributed chromatin and evident small knobs possibly corresponding to small amount and densely compacted heterochromatin that were more clearly visualised by fluorochromes (Figure 3D). The chromosomes in prophase, prometaphase, and metaphase showed uniform condensation and homogeneous appearance throughout the chromosome length, except in primary and secondary constrictions (Figures 1A, 1B, 1C and 2).

The nucleolar organiser regions (NORs) of the members of the genus Allium with the denomination of sativum are characterised by having a size equivalent to their respective short arms (Yüzbasioglu and Ünal, 2004; Peška et al., 2019). In fact, in prometaphase, it was possible to identify two clearly distended proximal NORs, sometimes also visualised in metaphase as large gaps (Figures 1B and 1C). In the "Roxo de Minas, Branco Mineiro - PI", and "Cateto Roxo 99" accessions (Figure 3F), one of these secondary constrictions observed in prometaphase appeared to be more distended than in its homologue, evidencing a chromosomal polymorphism.
The mean length of the chromosomes ranged from $8.46 \mu \mathrm{m}$ ("Sergipe" accession) to $14.22 \mu \mathrm{m}$ ("Roxo de Minas" accession), with chromosomal size ranging from $6.42 \mu \mathrm{m}$ to $17.79 \mu \mathrm{m}$ (Table 2 ). These values are similar to the range observed by Yüzbasioglu and Ünal (2004), differing in the smallest size $(7.32 \mu \mathrm{m})$ and for the largest size $(12.20 \mu \mathrm{m})$. However, the slight change identified in the comparison with previous results for the smallest and largest size might be due to small differences in chromosome condensation in the metaphases measured or by the use of overlay images with CMA/DAPI staining during morphometry analysis.

The karyotype formulas found were $6 \mathrm{M}+2 \mathrm{SM}$ and $7 \mathrm{M}$ $+1 \mathrm{SM}$. However, in view of the ratio values between the long and short $\operatorname{arm}(r)$ and the parameters of Levan et al. (1964), 8M (metacentric) was found for all accessions. This morphological classification considers that chromosomes with $r$ between 1.0 and 1.7 are metacentric and those with $r$ between 1.7 and 3.0 are submetacentric (SM). In the present study, the parameters of Guerra (1983) were used to establish an $r$ value between 1.0 and 1.49 as metacentric and an $r$ value between 1.5 and 2.99 as submetacentric. Thus, chromosome pairs 5, 6, or 7 of most accessions were at the threshold between metacentric and submetacentric, especially pair 5 , causing a difference in the chromosome classification of the accessions (Table 2). Konvicka and Levan (1972) found similar results, as they also obtained chromosome measurements at the threshold between the classification categories.

For karyotype asymmetry, the indices of Huziwara (1962), TF\%, and Zarco (1986), $A_{1}$ and $A_{2}$, were evaluated. These indices are mainly used to infer the taxonomic and evolutionary aspects among taxa (Paszko, 2006;
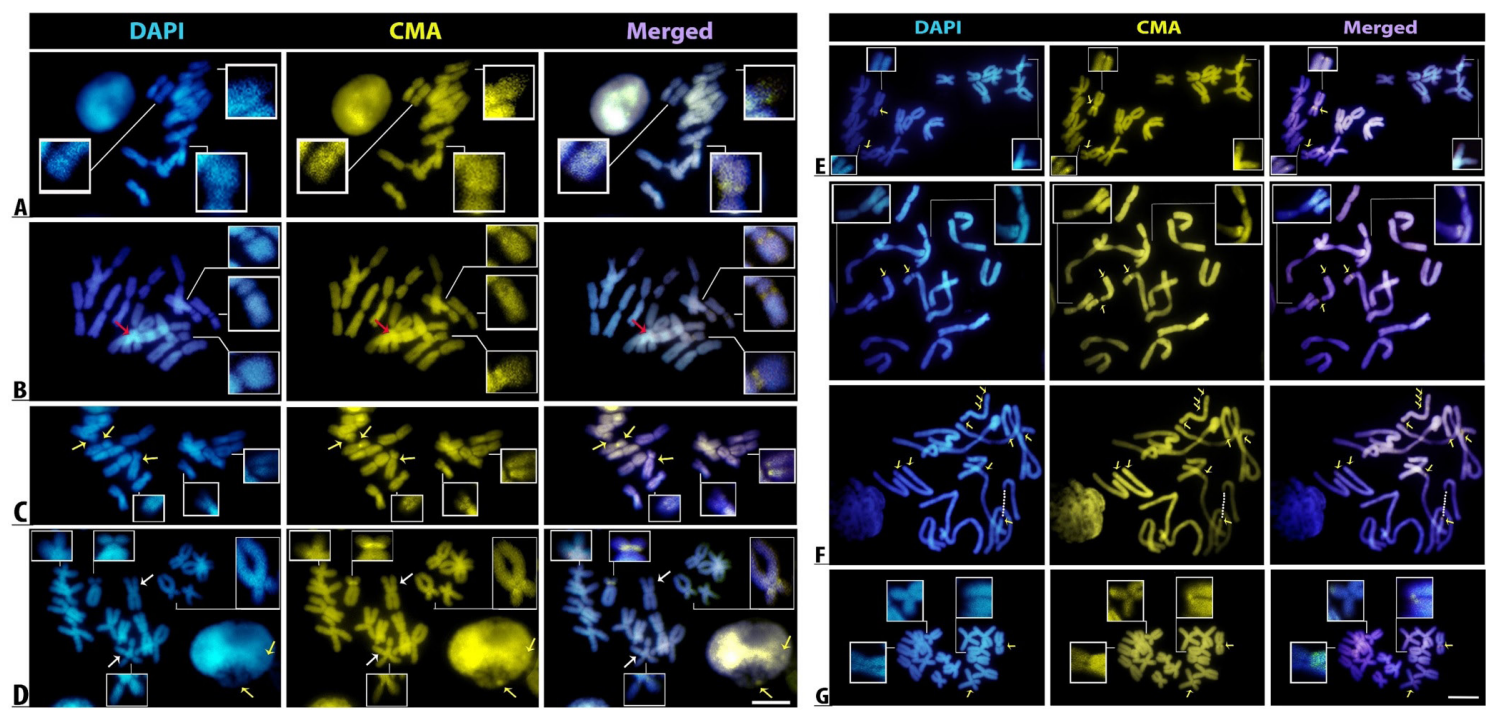

Figure 3. Double staining with CMA/DAPI in accessions "Sussuapara - PI" (A), "Santo Antônio de Lisboa" (B), "Catetinho do Paraná 1254" (C), "Branco Mineiro - PI" (D). Inserts highlight small CMA+/DAPI" bands. Yellow arrows indicate the CMA+/DAPI- bands more evident in chromosomes and interphase nuclei. Red arrows indicate $\mathrm{CMA}^{+}$bands in the overlaid chromosome (B). White arrows indicate gaps formed by condensation (D). Dots indicate distended nucleolar organiser regions (NORs) (f). Bar $=10 \mu \mathrm{m}$. Figure 2. Double staining with CMA/DAPI in accessions "Cateto Roxo 99" (E), "Roxo de Minas" (F) and "Sergipe" (G). Inserts highlight small CMA ${ }^{+}$DAPI" bands. Yellow arrows indicate the $\mathrm{CMA}^{+}$/DAPI- bands more evident in chromosomes and interphase nuclei. Dots indicate distended nucleolar organiser regions (NORs) $(\mathrm{F})$. Bar $=10 \mu \mathrm{m}$. 
Peška et al., 2019). In this study, these indices were used to identify differences in asymmetry between the evaluated accessions. The TF\% index is expressed as the ratio between the sum of the lengths of the short arms and the total length of the haploid complement, ranging from 0 to 0.5 according to increased symmetry. The intrachromosomal asymmetry index $\left(A_{1}\right)$ is based on the ratio between arms, and the interchromosomal asymmetry index $\left(A_{2}\right)$ is based on the ratio between the mean and standard deviation obtained from the length of the haploid set, ranging from 0 to 1 according to increased asymmetry.

In addition, a symmetrical karyotype is characterised by the predominance of metacentric and submetacentric chromosomes of approximately the same size (Paszko, 2006). Considering the karyotype formula and asymmetry indices, all accessions herein are symmetrical and showed a slight variation from 43.75 to 44.24 for $\mathrm{TF} \%, 0.21$ to 0.23 for $A_{1}$, and 0.15 to 0.17 for $A_{2}$ (Table 2 ). These values are similar to those found in garlic clones by Ordóñez et al. (2002), with $A_{1}$ ranging from 0.24 to 0.25 and with more divergent values for $A_{2}$, which ranged from 0.18 to 0.20 .

An analysis of variance (ANOVA) performed with the mean values of the TLHS, the long $\operatorname{arm}(\mathrm{q})$, and the short arm (p) values found were 6.38 and 3.80, respectively, being significant by F-test at $1 \%$ probability level (Table 3 ). However, as with the asymmetry index results, the mean values of total length and the lengths of the long and short arms subjected to Tukey's test at $5 \%$ probability level showed no significant differences between accessions, except for the "Roxo de Minas" accession, which differed from the others due to having the most decondensed chromatin in prometaphase (Table 4). This divergence identified by Tukey's test at $5 \%$ probability level resulted in significant ANOVA data.

Table 2. Accessions, diploid chromosome number, chromosome size range (CSR), mean ratio between chromosome arms ( $r$ ), karyotype formula (KF), total chromosome length (TCL), mean chromosome length (MCL), total length of the haploid set (TLHS), and the asymmetry indices of Huziwara (1962) (TF\%) and Zarco (1986) $\left(A_{1}\right.$ and $\left.A_{2}\right)$.

\begin{tabular}{|c|c|c|c|c|c|c|c|c|c|c|}
\hline Accession & $2 n$ & CSR $\mu \mathrm{m}$ & $\mathbf{r}$ & $\begin{array}{c}\text { KF } \\
\text { Guerra } \\
(1983)\end{array}$ & TCL $\mu \mathrm{m}$ & $\begin{array}{c}\text { MCL } \\
\mu \mathrm{m}\end{array}$ & $\begin{array}{c}\text { TLHS } \\
\mu \mathrm{m}\end{array}$ & TF\% & $A_{1}$ & $\mathrm{~A}_{2}$ \\
\hline Sussuapara - PI & 16 & $6.77-11.14$ & 1.41 & $6 \mathrm{M}+2 \mathrm{SM}$ & 145.24 & 9.08 & 72.62 & - & - & - \\
\hline Santo Antônio de Lisboa - PI & 16 & $7.64-12.22$ & 1.35 & $6 \mathrm{M}+2 \mathrm{SM}$ & 160.39 & 10.02 & 80.20 & 43.94 & 0.22 & 0.15 \\
\hline Catetinho do Paraná 1254 & 16 & $7.28-12.50$ & 1.32 & $6 \mathrm{M}+2 \mathrm{SM}$ & 159.48 & 9.97 & 79.74 & 44.19 & 0.21 & 0.17 \\
\hline Branco Mineiro - PI & 16 & $7.03-11.51$ & 1.32 & $7 \mathrm{M}+1 \mathrm{SM}$ & 149.29 & 9.33 & 74.65 & 44.24 & 0.21 & 0.16 \\
\hline Cateto Roxo 99 & 16 & $7.28-12.40$ & 1.34 & $6 \mathrm{M}+2 \mathrm{SM}$ & 158.64 & 9.91 & 79.32 & 43.75 & 0.23 & 0.17 \\
\hline Roxo de Minas & 16 & $10.27-17.79$ & 1.36 & $6 \mathrm{M}+2 \mathrm{SM}$ & 227.47 & 14.22 & 13.73 & 43.82 & 0.23 & 0.17 \\
\hline Sergipe & 16 & $6.42-10.41$ & 1.33 & $7 \mathrm{M}+1 \mathrm{SM}$ & 135.29 & 8.46 & 67.64 & 43.88 & 0.23 & 0.16 \\
\hline
\end{tabular}

Table 3. Mean values for the length of the long arm and short arm and total length expressed in micrometer ( $\mu \mathrm{m})$. Accessions followed by the same superscript letter were grouped by Tukey's test at the $5 \%$ significance level.

\begin{tabular}{lccc}
\hline \multicolumn{1}{c}{ Accessions } & Long Arm & Short Arm & Total Length \\
\hline Santo Antônio de Lisboa - PI & $5.62^{\mathrm{b}}$ & $4.41^{\mathrm{b}}$ & $10.02^{\mathrm{b}}$ \\
Catetinho do Paraná 1254 & $5.56^{\mathrm{b}}$ & $4.41^{\mathrm{b}}$ & $9.97^{\mathrm{b}}$ \\
Branco Mineiro - PI & $5.20^{\mathrm{b}}$ & $4.13^{\mathrm{b}}$ & $9.33^{\mathrm{b}}$ \\
Cateto Roxo 99 & $5.59^{\mathrm{b}}$ & $4.34^{\mathrm{b}}$ & $9.91^{\mathrm{b}}$ \\
Roxo de Minas & $7.99^{\mathrm{a}}$ & $6.23^{\mathrm{a}}$ & $14.22^{\mathrm{a}}$ \\
Sergipe & $4.75^{\mathrm{b}}$ & $3.71^{\mathrm{b}}$ & $8.46^{\mathrm{b}}$ \\
\hline
\end{tabular}

Table 4. Summary of the analysis of variance for the total length of the haploid set (TLHS) and the lengths of the long arm (q) and short $\operatorname{arm}(\mathrm{p})$ referring to mean morphometric parameters obtained for five replicates of metaphases from the "Santo Antônio de Lisboa - PI", “Catetinho do Paraná 1254", "Branco Mineiro - PI”, “Cateto Roxo 99”, "Roxo de Minas”, and "Sergipe” accessions. Variation source (VS), degree of freedom (DF), coefficient of variation (CV).

\begin{tabular}{ccccc}
\hline \multirow{2}{*}{ VS } & DF & \multicolumn{3}{c}{ Mean Squares } \\
\cline { 3 - 5 } & & TLHS & $\mathbf{q}$ & $\mathbf{p}$ \\
\hline Accessions & 5 & $20.00^{* *}$ & $6.38^{* *}$ & $3.80^{* *}$ \\
Residue & 24 & 1.35 & 0.44 & 0.86 \\
CV $(\%)$ & - & 11.28 & 11.48 & 11.21 \\
\hline
\end{tabular}

${ }^{* *}$ Significant at $1 \%$ probability level by F-test. 
Double staining with the fluorochromes CMA and DAPI revealed a small amount of heterochromatin GC-rich content and very small $\mathrm{CMA}^{+} / \mathrm{DAPI}^{-}$bands. The CMA bands had different staining intensities, receiving the symbol $\left(^{+}\right)$ according to the brightness of the signal emitted by the CMA fluorochrome. The smaller bands were even more discrete in chromosomes with a high compaction level; this observation could only be confirmed by observing the chromocenters formed in interphase nuclei or in more distended chromosomes (Figure 3).

The characterised accessions of $A$. sativum showed some similar chromosomes and other chromosomes with varying intensity, distribution, and number of $\mathrm{CMA}^{+} / \mathrm{DAPI}^{-}$ bands. The haploid set is represented by the ideogram for better visualisation of the differences between pairs of homologous chromosomes and between accessions (Figure 2). In the accessions studied herein, no $\mathrm{CMA}^{+} / \mathrm{DAPI}^{-}$ bands were observed in chromosome pairs 1,2, and 3, which are similar both in size and morphology and represent the largest chromosomes of the complement (Figures 2 and 3 ). In other chromosomes from different accessions, it was possible to observe discrete $\mathrm{CMA}^{+} / \mathrm{DAPI}^{-}$heterochromatin blocks mostly located near the centromere.

In all accessions, proximal $\mathrm{CMA}^{+} / \mathrm{DAPI}$ bands occurred in chromosome pairs 6 and 7, which may be associated with NORs (Besendorfer et al., 2002), although a distinct satellite between the accessions was observed in only one of the pairs, 6 or 7 . These chromosomes are described by a satellite region in the short arm, with pair 6 being more asymmetric than pair 7 (Konvicka and Levan, 1972). The intensity of these $\mathrm{CMA}^{+} / \mathrm{DAPI}-$ bands varied among pairs and among accessions, particularly in "Branco Mineiro - PI". For this accession, the band in one of the chromosomes of pair 6 was the most intense of all the evaluated accessions, indicating a greater number of GC sequences, which can be easily identified as a large chromocenter in interphase nuclei (see Figure 3D). Thus, the chromosome can be used as a potential marker for the identification of this accession.

Also in pair 6, small bands occurred in the distal region of the short arm in the accessions "Sussuapara - PI" and "Santo Antônio de Lisboa - PI" (Figures 2A, 3A, 2B and 3B). Very weak $\mathrm{CMA}^{+} / \mathrm{DAPI}-$ bands were found near the telomere on the long arm in one chromosome of the pair 4 in the accessions "Catetinho do Paraná 1254" and "Sergipe" (Figures 2C, 3C, 2G and 3G). Similar bands were identified in pair 5 of the "Cateto Roxo 99" accession and were evident in only one of the chromosomes in the "Roxo de Minas" ESALQ accession (Figures $2 \mathrm{~F}$ and $3 \mathrm{~F}$ ). The "Catetinho do Paraná 1254" accession contained CMA ${ }^{+} / \mathrm{DAPI}$ - blocks in the centre region of the long arm in one of the chromosomes of pair 8, as well as a distinct difference in the length of the long arm in one of the homologues of pair 7, suggesting loss of genetic material (Figures 2C and 3C). Polymorphisms in the sizes of chromosome pairs 6 and 7 were also identified in the accessions "Santo Antônio de Lisboa - PI", "Cateto Roxo 99", and "Roxo de Minas" (Figures 2B, 2E and 2F); additionally, polymorphisms were observed for the size in the chromosomes pair 7 of the "Sergipe" accession and in pair 8 of the "Branco Mineiro - PI" accession (Figures 2G and 2D, respectively). The "Cateto Roxo 99" accession exhibited heteromorphism in $\mathrm{CMA}^{+} / \mathrm{DAPI}^{-}$bands in pairs 6 and 7 (Figures 2E and 3E).

Variations in the distribution of the small heterochromatic bands found allowed the organisation of garlic accessions into three groups: group I - the "Sussuapara - PI", "Santo Antônio de Lisboa - PI", and "Branco Mineiro - PI" accessions, which showed $\mathrm{CMA}^{+}$/DAPI-bands only in chromosome pairs 6 and 7; group II - the "Catetinho do Paraná 1254" and "Sergipe" accessions, which showed $\mathrm{CMA}^{+} / \mathrm{DAPI}^{-}$bands in chromosome pairs 4, 6, and 7; and group III - the "Cateto Roxo 99" and "Roxo de Minas" accessions, which showed $\mathrm{CMA}^{+}$/DAPI- bands in chromosome pairs 5, 6, and 7 (Table 5).

In the genus Allium, some other variations of heterochromatic bands have been found. According to Jamilena et al. (1990) and Peška et al. (2019), polymorphisms have been observed in a wild population of $A$. subvillosum (Liliaceae). The absence of the nucleolar organiser region (NOR) in one member of the third chromosome pair is related to a variation in the NOR-associated heterochromatin (the chromosomes without NOR do not have the distal C-band from the satellite, but the proximal C-band may be present). In A. sativum, Yüzbasioglu and Ünal (2004) identified C-bands in the pericentromeric region of pairs 1 and 4 and in the region near the satellite of pair 5, which differs from the results presented by Cortes et al. (1983), who visualised C-bands in the telomeric region of pair 4 and in the proximal region of the short arms of pairs 6 and 7 and distal bands on the long arms of pairs 7 and 8 . In A. cepa, a closely related species, $\mathrm{CMA}^{+}$heterochromatin bands are observed clearly only at the end of chromosomes, suggesting that the species of subgenus Cepa (A. cepa and A. fistulosum) show a heterochromatic pattern distinct from subgenus Allium (A. sativum and A. porrum) (Kim et al., 2002). Its heterochromatic polymorphism found can be associated with potential morphological and/or agronomical features that can be used in future garlic genetics breeding. Further cytomolecular studies using specific genes of interest as FISH (Fluorescent in situ Hybridization) probes are needed to confirm this association.

It is believed that variations in the amount and distribution of heterochromatin of the A. sativum accessions analysed in this study are due to the accumulation of small structural changes that mainly involve repetitive DNA sequences and fixation thereof due to the different environments in which the plants have been grown for dozens of years, unlike the genotypes previously reported for other regions (Puiatti and Ferreira, 2005). These polymorphisms are also related to the tendency for the accumulation or elimination of heterochromatin derived from the evolutionary process (Guerra, 2000). Hence, cytogenetics as a tool allows inferences about cytogenetic events associated with chromosomal evolution, even when these changes are very subtle at the karyotype level in different genotypes. The polymorphisms identified in our study confirm the genetic diversity within A. sativum species. These results supply additional aids about the landraces varieties conserved at germplasm banks and contribute for future studies of garlic genetic breeding programs. 


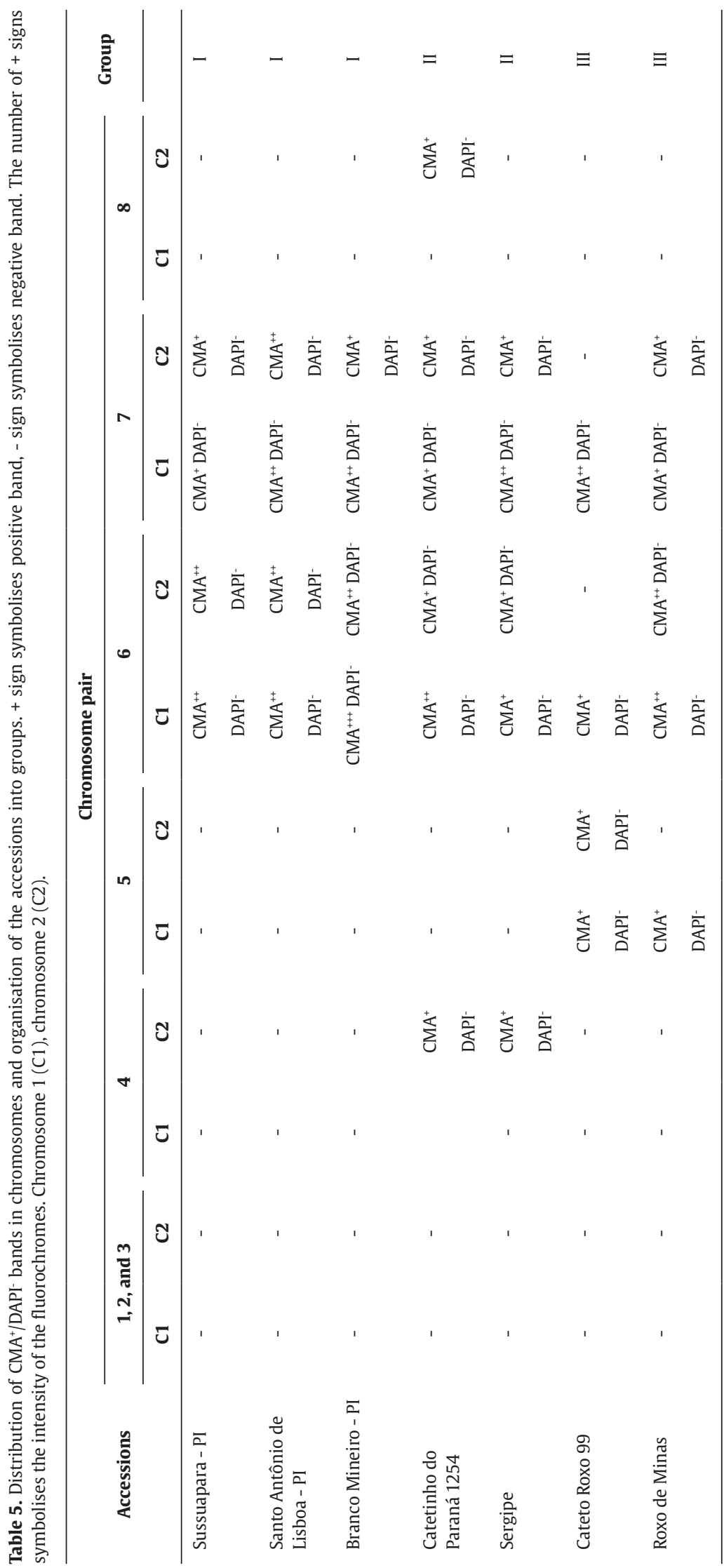




\section{References}

BESENDORFER, V., SAMARDZIJA, M., ZOLDOS, V., SOLIC, M.E. and PAPEŠ, D., 2002. Chromosomal organization of ribosomal genes and NOR-associated heterochromatin, and NOR activity in some populations of Allium commutatum Guss. (Alliaceae). Botanical Journal of the Linnean Society, vol. 139, no. 1, pp. 99-108. http:/ dx.doi.org/10.1046/j.1095-8339.2002.00047.x.

CORDEIRO, J.M., KAEHLER, M., SOUZA, L.G. and FELIX, L.P., 2020. Heterochromatin and numeric chromosome evolution in Bignoniaceae, with emphasis on the Neotropical clade Tabebuia alliance. Genetics and Molecular Biology, vol. 43, no. 1, pp. e20180171. http://dx.doi.org/10.1590/1678-4685gmb-2018-0171. PMid:31429855.

CORTES, F., GONZALEZ-GIL, G. and HAZEN, M.J., 1983. C-banding and sister chromatid exchanges in three species of the genus Allium (A. cepa, A. ascalonicum and A. sativum). Caryologia, vol. 36, no. 3, pp. 203-210. http://dx.doi.org/10.1080/000871 14.1983.10797661.

CRUZ, C.D., 2013. GENES: a software package for analysis in experimental statistics and quantitative genetics. Acta Scientiarum. Agronomy, vol. 35, no. 3, pp. 271-276. http://dx.doi. org/10.4025/actasciagron.v35i3.21251.

EBERT, A.W., 2020. The role of vegetable genetic resources in nutrition security and vegetable breeding. Plants, vol. 9, no. 6, pp. 736. http://dx.doi.org/10.3390/plants9060736. PMid:32545299.

GUERRA, M. and SOUZA, M.J., 2002. Como observar cromossomos: um guia de técnicas em citogenética vegetal, animal e humana. Ribeirão Preto: Editora FUPEC, 200 p.

GUERRA, M., 1983. O uso de Giemsa na citogenética vegetal: comparação entre a coloração simples e o bandeamento. Ciência e Cultura, vol. 35, pp. 190-193.

GUERRA, M., 2000. Patterns of heterochromatin in plant chromosomes. Genetics and Molecular Biology, vol. 23, no. 4, pp. 1029-1041. http://dx.doi.org/10.1590/S141547572000000400049 .

HONORATO, A.R.F., NEGREIROS, M.Z., RESENDE, F.V., LOPES, W.A.R. and SOARES, A.M., 2013. Avaliação de cultivares de alho na região de Mossoró. Revista Caatinga, vol. 26, no. 3, pp. 80-88.

HUZIWARA, Y., 1962. Karyotype analysis in some genera of Compositae. VIII, Further studies on the chromosome of Aster. American Journal of Botany, vol. 49, no. 2, pp. 116-119. http:// dx.doi.org/10.1002/j.1537-2197.1962.tb14916.x.

JAMILENA, M., REJÓN, C.R. and REJÓN, M.R., 1990. Variation in the heterochromatin and nucleolar organizing regions of Allium subvillosum L. (Liliaceae). Genome, vol. 33, no. 6, pp. 779-784. http://dx.doi.org/10.1139/g90-116.

JAYASWALL, K., SHARMA, H., BHANDAWAT, A., SAGAR, R., YADAV, V.K., SHARMA, V., MAHAJAN, V., ROY, J. and SINGH, M., 2019. Development of intron length polymorphic (ILP) markers in onion (Allium cepa L.), and their cross-species transferability in garlic (A. sativum L.) and wild relatives. Genetic Resources and Crop Evolution, vol. 66, no. 7, pp. 1379-1388. http://dx.doi org/10.1007/s10722-019-00808-3.

KHAR, A., HIRATA, S., ABDELRAHMAN, M., SHIGYO, M. and SINGH, H., 2020. Breeding and genomic approaches for climate-resilient garlic. In: C. KOLE, ed. Genomic designing of climate-smart vegetable crops. London: Springer, pp. 359-383. http://dx.doi. org/10.1007/978-3-319-97415-6_8.

KIM, E.S., PUNINA, E.O. and RODIONOV, A.V., 2002. Chromosome CPD (PI/DAPI)- and CMA/DAPI-Banding Patterns in Allium cepa L. Russian Journal of Genetics, vol. 38, no. 4, pp. 489-496. http://dx.doi.org/10.1023/A:1015250219322. PMid:12018166.
KONVICKA, O. and LEVAN, A., 1972. Chromosome studies in Allium sativum. Hereditas, vol. 72, no. 1, pp. 129-148. http://dx.doi. org/10.1111/j.1601-5223.1972.tb01035.x.

LANDAU, E., SILVA, G.A., MOURA, L., HIRSCH, A. and GUIMARAES, D., 2020. Dinâmica da produção agropecuária e da paisagem natural no Brasil nas últimas décadas: cenário histórico, divisão política, características demográficas, socioeconômicas e ambientais. Brasília: Embrapa Milho e Sorgo.

LEVAN, A., 1935. Cytological studies in Allium, VI - the chromosome morphology of some diploid species of Allium. Hereditas, vol. 20, no. 3, pp. 289-330. http://dx.doi.org/10.1111/j.1601-5223.1935. tb03192.x

LEVAN, A., FREDGA, K. and SANDBERG, A.A., 1964. Nomenclature for centromeric position on chromosomes. Hereditas, vol. 52, no. 2, pp. 201-220. http://dx.doi.org/10.1111/j.1601-5223.1964. tb01953.x.

MALIK, M.Q., MUJIB, A., GULZAR, B., ZAFAR, N., SYEED, R., MAMGAIN, J. and EJAZ, B., 2020. Genome size analysis of field grown and somatic embryo regenerated plants in Allium sativum L. Journal of Applied Genetics, vol. 61, no. 1, pp. 25-35. http://dx.doi. org/10.1007/s13353-019-00536-5. PMid:31919659.

MARTINS, L.V., PERON, A.P., LOPES, A.C.A., GOMES, R.F.L., CARVALHO, R. and FEITOZA, L.L., 2018. Heterochromatin distribution and histone modification patterns of H4K5 acetylation and phosphorylation in Capsicum L. Crop Breeding and Applied Biotechnology, vol. 18, no. 2, pp. 161-168. http://dx.doi. org/10.1590/1984-70332018v18n2a23.

MUKHERJEE, A. and ROY, S.C., 2012. Karyotype analysis of five species of Allium. Indian. Journal of Fundamental and Applied Life Sciences, vol. 2, no. 1, pp. 374-383.

NICHOLS, C., 1941. Spontaneous chromosome aberrations in Allium. Genetics, vol. 26, no. 1, pp. 89-100. http://dx.doi.org/10.1093/ genetics/26.1.89. PMid:17247000.

ORDÓÑEZ, A., TORRES, L.E., HIDALGO, M.G. and MUÑOZ, J.O., 2002. Análisis citológico de una variante genetic somática de ajo (Allium sativum L.) tipo rosado. Agriscientia, vol. 19, pp. 37-43.

PALADINI, S., 2019. Custom unions and common markets as economic security fault lines: the garlic case. In: A. RUYTER and B. NIELSEN, eds. Brexit negotiations after article 50: assessing process, progress and impact. Bingley: Emerald Publishing, $113 \mathrm{p}$.

PASZKO, B., 2006. A critical review and a new proposal of karyotype asymmetry indices. Plant Systematics and Evolution, vol. 258, no. 1-2, pp. 39-48. http://dx.doi.org/10.1007/s00606-005-0389-2.

PEŠKA, V., MANDÁKOVÁ, T., IHRADSKÁ, V. and FAJKUS, J., 2019. Comparative dissection of three giant genomes: Allium cepa, Allium sativum, and Allium ursinum. International Journal of Molecular Sciences, vol. 20, no. 3, pp. 733. http://dx.doi. org/10.3390/ijms20030733. PMid:30744119.

PUIATTI, M. and FERREIRA, F.A., 2005. Cultura do alho. In: P.C.R. FONTES, ed. Olericultura: teoria e prática. 1. ed. Viçosa: UFV, pp. 299-322.

QUERINO, B.C., FERRAZ, M.E., MATA-SUCRE, Y., SOUZA, L.G.R. and FELIX, L.P., 2020. Cytomolecular diversity of the subtribe Laeliinae (Epidendroidae, Orchidaceae) suggests no relationship between genome size and heterochromatin abundance. Plant Systematics and Evolution, vol. 306, no. 2, pp. 19. http://dx.doi. org/10.1007/s00606-020-01650-2.

RUP, L.A.L., 2019. Crop improvement utilizing biotechnology. London: CRC Press.

SANTOS, K.B. and GOMES, J.M.A., 2012. Aspectos ambientais e de mercado da involução na produção de alho na microrregião de Picos. In: Anais do $6^{\circ}$ Encontro da Associação Nacional de 
Pós-graduação e Pesquisa em Ambiente em Sociedade, 2012, Belém. Belém: UFPA.

SCHWEIZER, D. and AMBROS, P.F., 1994. Chromosome banding. Stain combinations for specific regions. Methods in Molecular Biology, vol.29, pp. 97-112. http://dx.doi.org/10.1385/0-89603289-2:97. PMid:7518289.

SUKIAS, S.JP. and MURRAY, B.G., 1990. Cytological examination of three cultivars of garlic (Allium sativum $\mathrm{L}$.) by C-banding and flow cytometry. NewZealand Journal of Crop and Horticultural Science, vol. 18, no. 1, pp. 17-21. http://dx.doi.org/10.1080/01140671.1990.10428065.

XIE-KUI, C., AO, C.-Q., ZHANG, Q., CHEN, L.-T. and LIU, J.-Q., 2008. Diploid and tetraploid distribution of Allium przewalskianum Regel. (Liliaceae) in the Qinghai-Tibetan Plateau and adjacent regions. Caryologia, vol. 61, no. 2, pp. 192-200. http://dx.doi. org/10.1080/00087114.2008.10589629.

YOSHIMOTO, N. and SAITO, K., 2019. S-Alk (en) ylcysteine sulfoxides in the genus Allium: proposed biosynthesis, chemical conversion, and bioactivities. Journal of Experimental Botany, vol. 70, no. 16, pp. 4123-4137. http://dx.doi.org/10.1093/jxb/ erz243. PMid:31106832.

YÜZBASIOGLU, D. and ÜNAL, F., 2004. Karyotyping, C- and NOR banding of Allium sativum L. (Liliaceae) cultivated in Turkey. Pakistan Journal of Botany, vol. 36, no. 1, pp. 343-349.

ZARCO. C. R., 1986. A new method for estimating karyotype asymmetry. Taxon, vol. 35, no. 3, pp. 526-530. https://doi. org/10.2307/1221906. 